\title{
Aus Prenfizen.
}

Neuregelung bex Befoldug ber Förfter.

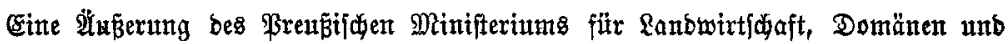
Forften zur Stellungnahme ber preusifden Förfter zat besorftehenden Reuoronung ber Befolbunggoerb̧ăltniffe ber Förfter, in\&bejondere zu bem unter bem 19. Februar b. S. in

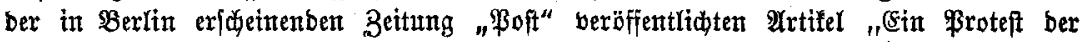

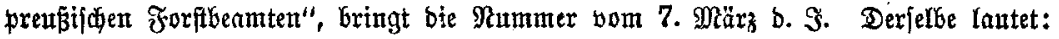

"Bis zum Frïhjahr 1919 Gaben bie prentifidjen Stant8förfter ftets angeftreft, bei

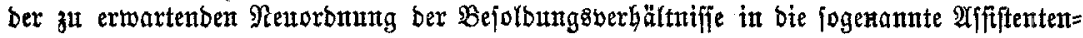
tlafie zu tommen. Ditejes Streben wurbe bon ber Staatsforftoerwaltung anertannt. Seitbem verfolgen bie Föriter bas Biel, ben $\Re$ egierungsjefretären gleidjgeftellt zu

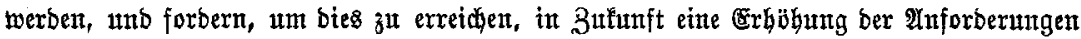

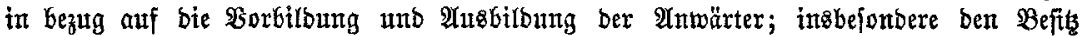

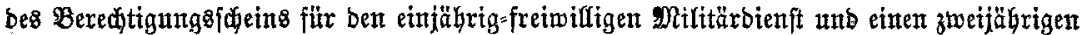
Bejuch ber Forftlebrlingsidule, beren Rebrgang bisher einjäbrig ift. Die Staat8forit=

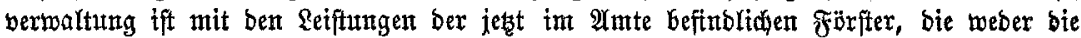

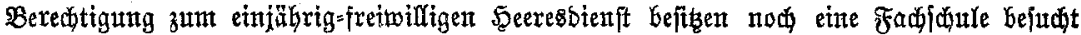

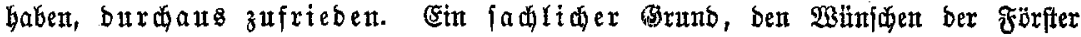
nadzulommen, liegt baher nidjt yor.

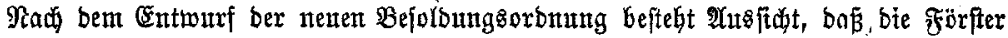
in bie (S) ruppe 6 fommen, welde bie Oberajifftenten und alle Sefretäre umfap̧t, weldye bie Regierungsfefretärprïfung nidjt abgelegt baben. Die Förfter lönneft bamit wohl ghfrieben fein. Solften bie Förfter, wie ein Tetl won ihnen bebanerfiderweife

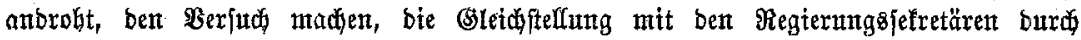

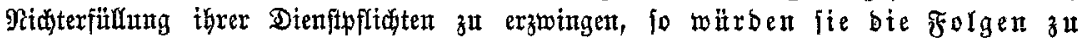
tragen baben.

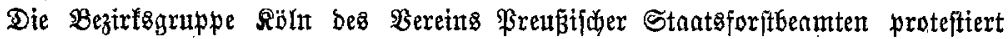

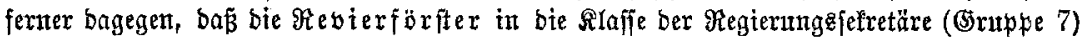
fommen follen. Sie bätten Dem förfterftanbe gegenitbex nidbt borau unb bürften bon

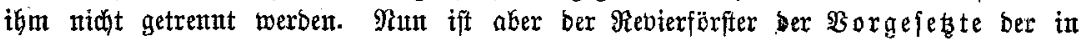
jeinem Dienftbezinfe befduäftigten Fürfter utnb bat ben Dberförfter in eintzefnen Dienf: gejdäften, befonbers bei ber Reitung unb Benuffidtigung ber Betriebsarbeiten, zu ver= treten. (Es erideint besbalb butchaus geredjtfertigt unb burd bie für bie neue $\mathfrak{B} e=$

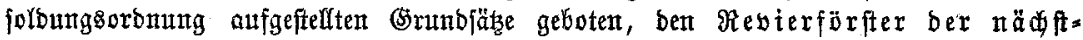
Gögeren $\mathfrak{B}$ efolbungographe einzurei gen.

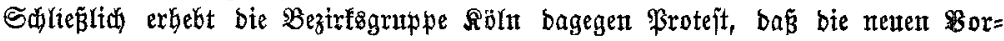

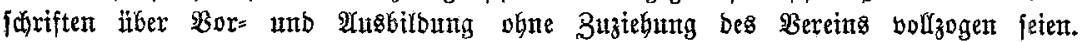

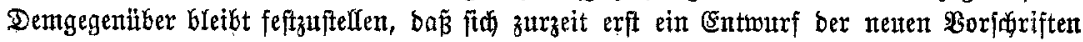

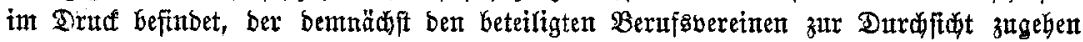
unb bann. mit ifnen gemeinfan beraten werben wirb. Fon biejer Sadlage iff ber Berein \$rettîtitier Staatgforftbeamten unterridtet."

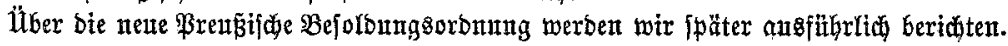

